\title{
Posht-e-Badam Metallogenic Block (Central Iran): A suitable zone for REE mineralization
}

\author{
Mir Ali Asghar Mokhtari* \\ Department of Geology, Faculty of Science, University of Zanjan, Zanjan, Iran
}

Received: January 8, 2015; accepted: April 13, 2015

One of the most important ores for REE mineralization are iron oxide-apatite (IOA) deposits. The Posht-e-Badam Block (PBB) is a part of the Central Iranian geostructural zone which is the host of most important Fe deposits of Iran. Exploration studies of the IOA deposits within the PBB (e.g. Esphordi, Gazestan, Zarigan, Lak-e-Siah, Sechahoun, Chahgaz, Mishdovan, Cheshmeh Firouzi and Shekarab) demonstrate that these deposits contain high contents of REE. Concentrations of $\sum$ REE in the most important IOA deposits of the PBB include the following: the Esphordi deposit varies between 1.2 and $1.88 \%$, the Gazestan deposit between 0.17 and $1.57 \%$, the Zarigan deposit between 0.5 and $1.2 \%$ and the Lak-e-Siah deposit varies between 0.45 and $1.36 \%$. Concentrations of $\sum$ REE within the apatite crystals present within the IOA ores in the Esphordi, Lak-e-Siah and Homeijan deposits have ranges between $1.9-2.54 \%, 1.9-2.16 \%$ and of $2.55 \%$, respectively. These elements are mainly concentrated in apatite crystals, but other minerals such as monazite, xenotime, bastnasite, urtite, alanite, thorite, parisite-synchysite and britholite have been recognized as hosts of REEs, as small inclusions within the apatite crystals, and in subsequent carbonate, hematite-carbonate and quartz veins and veinlets. Given the extent of this block and the presence of several IOA deposits within this block, and also the high grades of REEs within these deposits, one can reasonably state that it is obvious that there are significant resources of REEs in this part of Iran.

Keywords: Central Iran, iron oxide-apatite (IOA) deposits, Posht-e-Badam Block, REE mineralization, Esphordi, Choghart

\footnotetext{
* Corresponding address: Boulevard of University, 45371-38791, Zanjan, Iran;

E-mail: amokhtari@znu.ac.ir
} 


\section{Introduction}

The most important REE ores include peralkaline-alkaline rocks, carbonatites, placers, iron-oxide-copper-gold (IOCG) deposits, iron oxide-apatite (IOA) deposits, pegmatites, vein deposits, skarn deposits and residual deposits (Long et al. 2010). The iron-oxide-copper-gold deposits (IOCG) have been recognized as a distinct deposit type only since the discovery of the giant Olympic Dam deposit in South Australia in the 1980s. The Olympic Dam deposit is unusual in that it contains large amounts of rare earth elements and uranium (Long et al. 2010). Among the iron ores of the world, there is a specific group of occurrences composed of the magnetite-hematite-apatite assemblage (IOA deposits) which are considered as Kiruna-type magnetite-apatite deposits. Rare earth elements (REE) are characteristically elevated in Kiruna-type deposits (Parak 1975; Frietsch and Perdahl 1995; Kerr 1998). REEs tend to partition into apatite, but often provide distinctive accessory mineralogies (Harlov et al. 2002).

The Posht-e-Badam Block (PBB) is a part of Central Iranian geostructural zone. This block is a metallogenic/tectonic province of the Infra-Cambrian age that is host to the most important Fe deposits of Iran between Bafq City to the south and the town of Posht-e-Badam to the north (Figs 1 and 2). Most of these deposits (e.g. Choghart, Chadormalou, Esphordi, Lak-e-Siah, Sechahoun, Cahgaz and Gazestan) are composed of magnetite along with apatite.

Most of the IOA deposits within the PBB were investigated mainly for their mineralogy and genesis; in some cases, it was extended to concentration of REEs within these deposits (Abedian 1983; Darvish Zadeh 1983; Samani and Babakhani 1990;
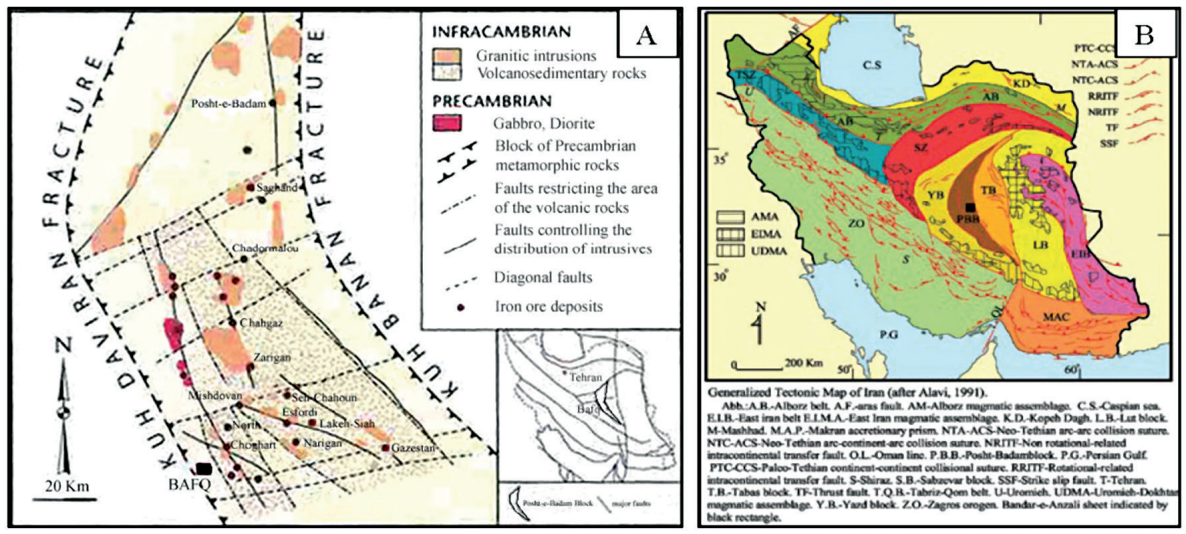

Fig. 1

A: Posht-e-Badam Metallogenic Block, surrounded by the Kuh Banan Fault (to the east) and the Kuh Daviran Fault (to the west). Locations of the most important Fe-P deposits are shown (NISCO 1980). B: Location of the PBB between the Yazd and Tabas Blocks. Locations of the major IOA deposits in this block are indicated by small black squares 
Daliran 1990; Forster and Jafar Zadeh 1994; Samani 1998, 1999; Rahmani and Mokhtari 2002; Mokhtari et al. 2003, 2008, 2013).

In this study the results of the REE exploration project within the PBB are presented. This project was carried out by the author as part of the exploration projects of the Geological Survey of Iran.

\section{Research method}

This study is in two parts: field work and laboratory investigations. Field work includes sampling from the IOA ores in the PBB for analyzing and determination of REE concentrations. Sampling was carried out based on a rare element exploration project of the Geological Survey of Iran. On this basis, IOA ores of the PBB were considered for sampling. Former studies indicated that the mentioned IOA ores demonstrated

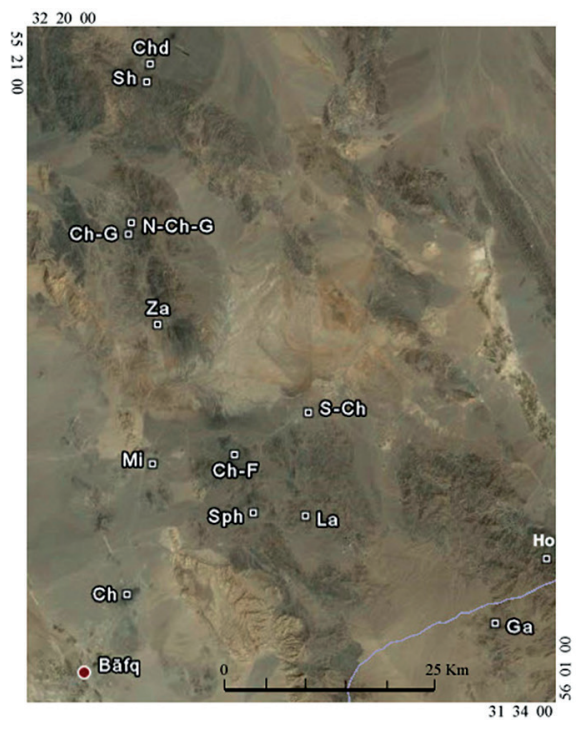

Fig. 2

Location map of the investigated IOA deposits within the scope of this study on satellite image (Ch: Choghart, Sph: Esphordi, La: Lak-e-Siah, Ga: Gazestan, Ho: Homeijan, Mi: Mishdovan, Ch-F: Cheshmeh Firouzi, S-Ch: Sechahoun, Za: Zarigan, Ch-G: Chahgaz, N-Ch-G: north of Chahgaz, Sh: Shekarab, Chd: Chadormalou) high concentrations of REEs. The samples were mainly taken from the P-rich parts of the different IOA ores within the PBB. Sampling was with chip samples in which each sample was about one kilogram in weight. For some IOA ores, apatite crystals were separated for analyzing. In the course of the laboratory work, 57 P-rich IOA ore samples and 8 samples from the apatite crystals were analyzed for REEs and other rare elements by the ICP-MS method (Table 1). These analyses were carried out in the ALS Chemex Laboratory in Canada. The multi-acid digestion method was used to dissolve all minerals, to provide near total values for all elements. The detection limits of the analyzed elements are shown in Table 1.

\section{Geology}

The PBB is a metallogenic/tectonic province in the Central Iranian zone (Stöcklin 1968; Alavi 1991; Fig. 1). This block is located between the Yazd Block to the west and the Tabas Block, together with the Lut Block, further to the east. Furthermore, it is bordered by two major fault zones: The Kuh Daviran or Posht-e-Badam Fault to the west and the Kuh Banan Fault to the east (Fig. 1). This zone is a narrow N-S trending 


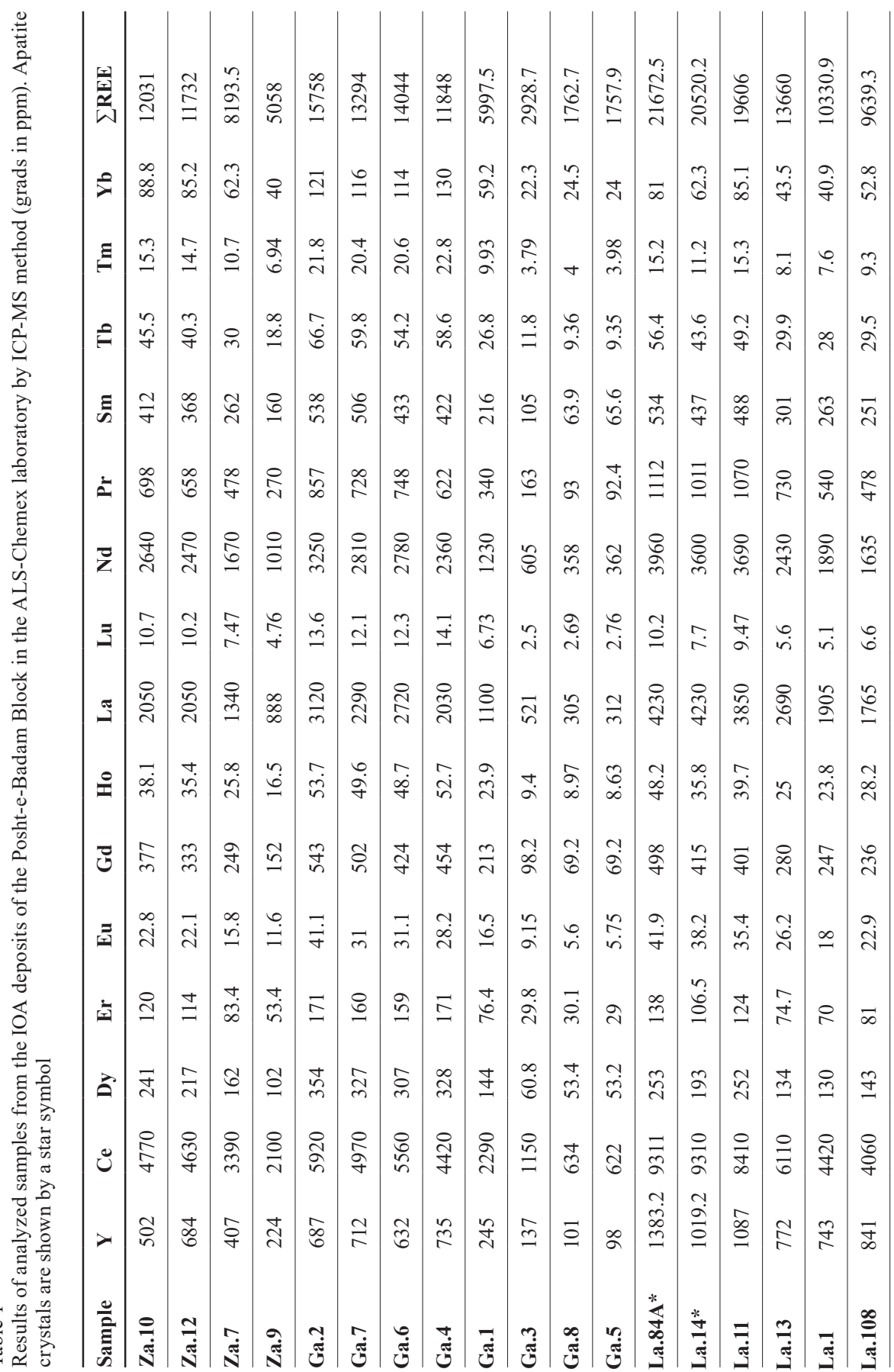




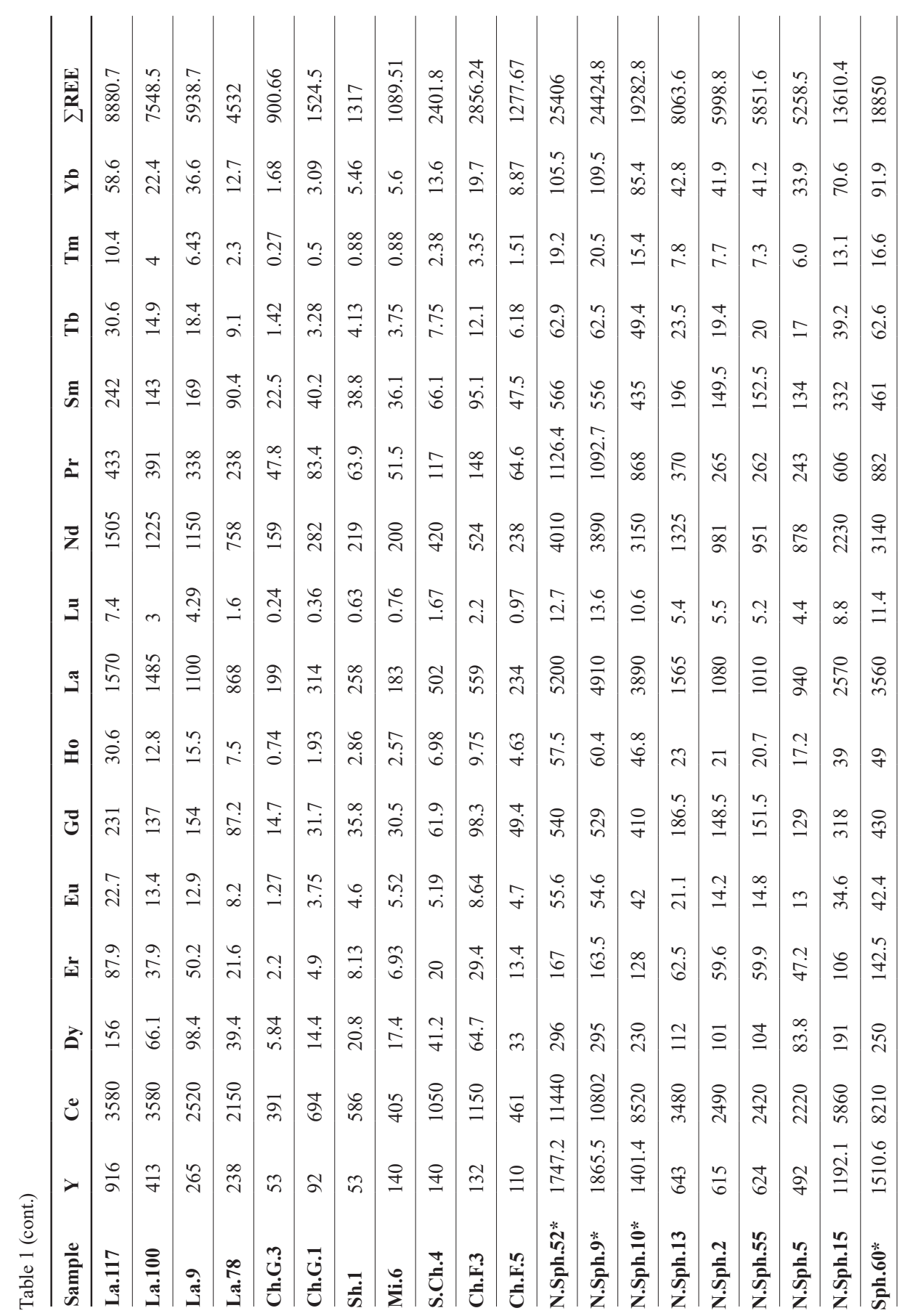




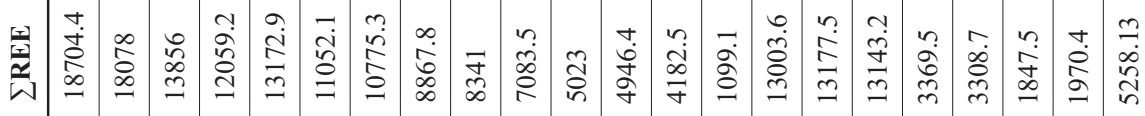

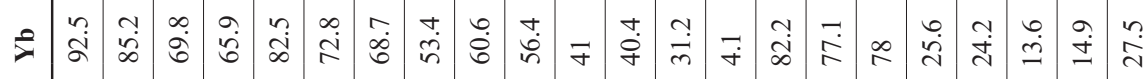

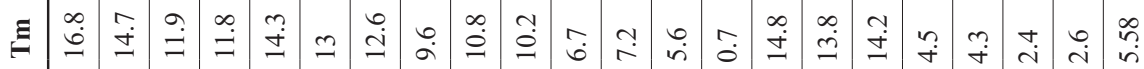

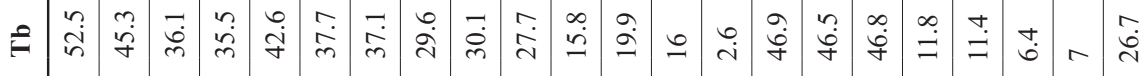

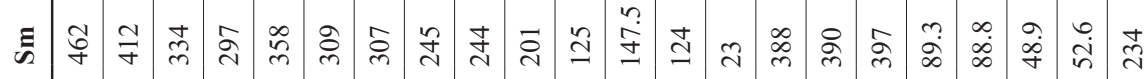

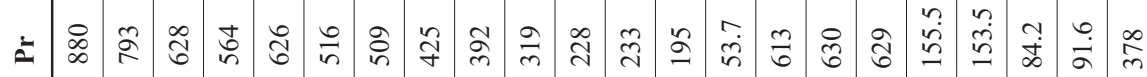

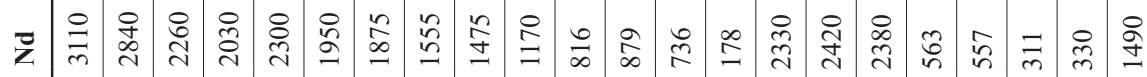

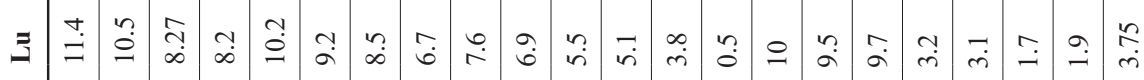

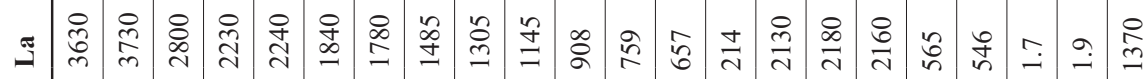

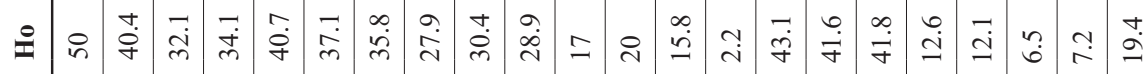

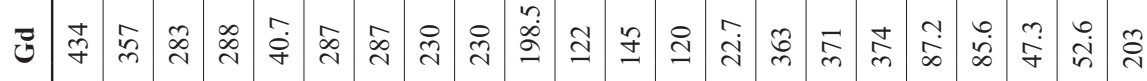

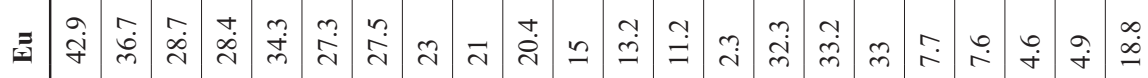

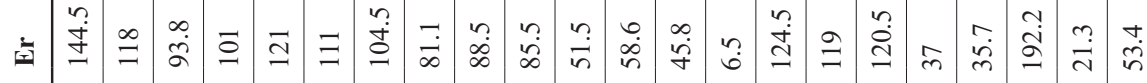

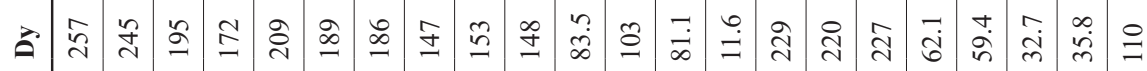

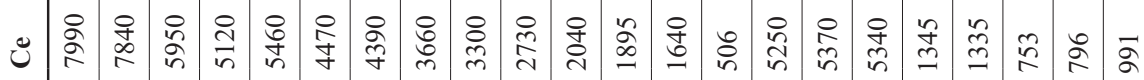

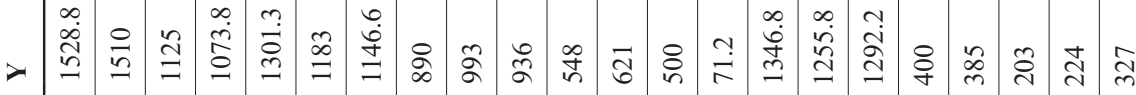

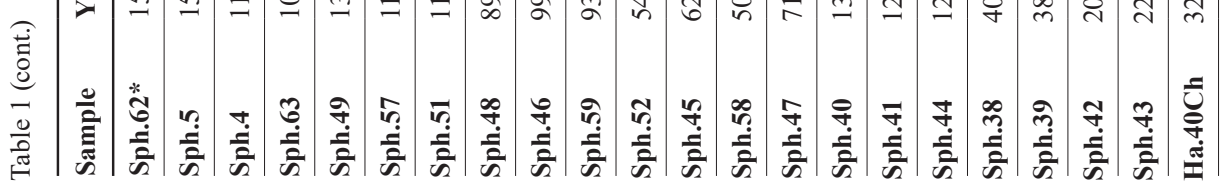




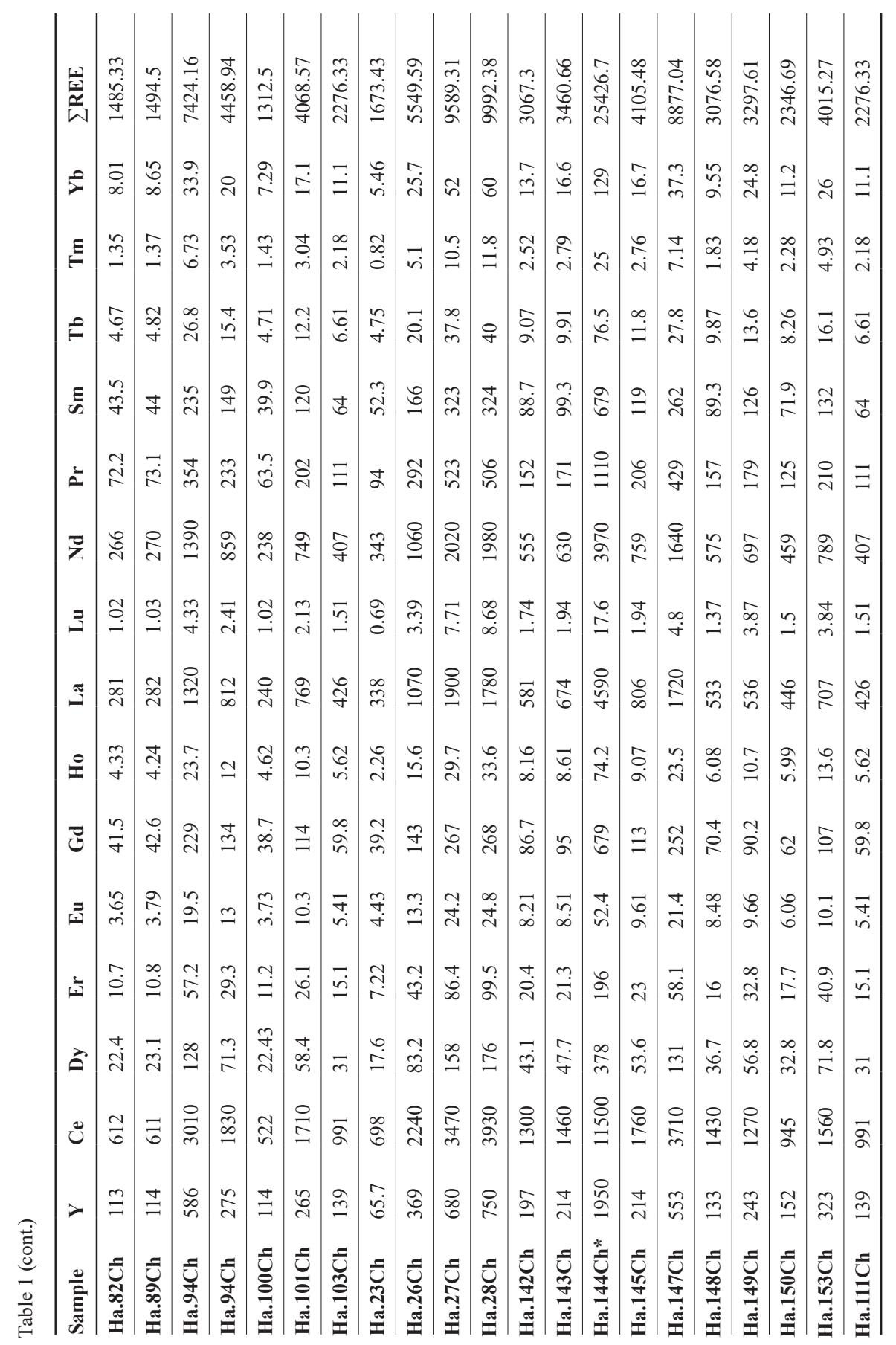


rift zone (Berberian and King 1981; Samani 1993, Daliran et al. 2009). Rifting took place in the late Precambrian and is characterized by sequences of non-metamorphic volcanic and volcano-sedimentary rocks, dolomitic limestone, local evaporates, bimodal volcanism, large sub-volcanic granitic bodies, syenite, gabbro and later diabasic dykes. Iron-ore deposits, apatite-bearing magmatic rocks which are known as apatitites (Daliran 1999), $\mathrm{Pb}-\mathrm{Zn}$ ores and $\mathrm{Th}-\mathrm{U}$ mineralization are related to this riftogenic event (Daliran 1990; Samani 1993). The Early Cambrian magmatism has been attributed to an arc setting by Ramazani and Tucker (2003) whereas the predominantly bimodal volcanism and its alkalic character led Samani (1998), Daliran (2002) and Daliran et al. $(2009,2010)$ to favor an extensional episode during or shortly after arc magmatism.

The PBB constitutes the most significant Fe-oxide and phosphate deposits in the world. It contains reserves of over 2 billion tons of Fe (NISCO 1980) within more than 34 major magnetic anomalies in a $7,500 \mathrm{~km}^{2}$ area. Among these targets, 14 have been defined as major deposits with over 1 billion tons of high grade Fe ore (53-65\%) (Taghizadeh 1976). The most economic iron ores consist of magnetite with apatite (e.g. at Choghart, Chadormalou, Esphordi, Zarigan, Lak-e-Siah, Gazestan, Sechahoun, Mishdovan, etc.; Figs 1 and 2). SSE-NNW fault lines were important for the tectonic evolution of these ores (Daliran 1990).

The IOA ore bodies of the PBB are hosted by a Lower Cambrian volcano-sedimentary sequence (also known as Saghand Formation) composed of acidic to basic lavas, pyroclastic-epiclastic rocks, intercalated carbonates which are associated with number of mafic and felsic intrusions (Samani 1993; Jami 2005; Torab 2010). Samani (1993) believed that the Saghand Formation was formed between 750 and $550 \mathrm{Ma}$ ago in a riftogenic setting. Volcanic rocks are mainly rhyolitic and rhyodacitic in composition and the sedimentary rocks are mainly dolomite. These ore bodies are commonly associated with pervasively altered acidic-intermediate tuffs. Some IOA ores of this block are associated with green rocks (Daliran 1990; Samani 1993). These rocks are probably the result of alteration in K-feldspars rich intrusions (Daliran 1990). Some researchers (e.g. Samani 1993) called these rocks as metasomatite. In addition to IOA ores, there are several non-ferrous ore bodies containing $\mathrm{Pb}-\mathrm{Zn}$ (Kushk mine), Mn (abundant Narigan mine) and U (Figs 1 and 2). Pebbles of the iron-oxide ores found in the basal Cambrian conglomerate in the Zarigan area (Haghipour 1975) demonstrate that Fe mineralization occurred during Infra-Cambrian.

\section{REEs mineralization}

IOA ores of the PBB are composed of magnetite ( \pm hematite \pm martite) and magnetite-apatite. These ores are present in veins, dykes and in massive form within the Lower Cambrian volcano-sedimentary sequence host rocks. In most of these deposits (e.g. Gazestan, Esphordi, Zarigan and Lak-e-Siah), euhedral apatite crys- 
tals are present in the magnetite or in the matrix of green rocks with porphyroidic to pegmatoidic texture (Fig. 3). Furthermore, in some deposits (e.g. Esphordi), the concentration of fine-grained apatite crystals formed phosphatic zones within and around the iron ore bodies and green rocks. These deposits were classified as Kiruna-type iron ore deposits (Darvish Zadeh 1983; Daliran 1990; Kryvdik and Mykhaylov 2001; Jami 2005; Torab and Lehman 2008; Torab 2010; Bumeri 2013; Mokhtari et al. 2013).

There are two generations of apatite crystals in the most of these deposits. The first generation includes coarse grained euhedral crystals, and the second generation is made up of fine-grained crystals that are present in the Fe ore matrix. Usually coarse-grained crystals contain inclusions of REE minerals such as monazite, bastnasite, xenotime, and alanite (Kryvdik and Mykhaylov 2001; Jami 2005; Torab and Lehman 2008; Torab 2010; Stosch et al. 2011; Bumeri 2013). Apatite crystals from the PBB are fluorine-rich and rather low in chlorine (Jami 2005; Stosch et al. 2011); this is common for apatite from felsic to intermediate (as well as other) magmatic rocks and independent of their relation to ore systems (Piccoli and Candela 2002).
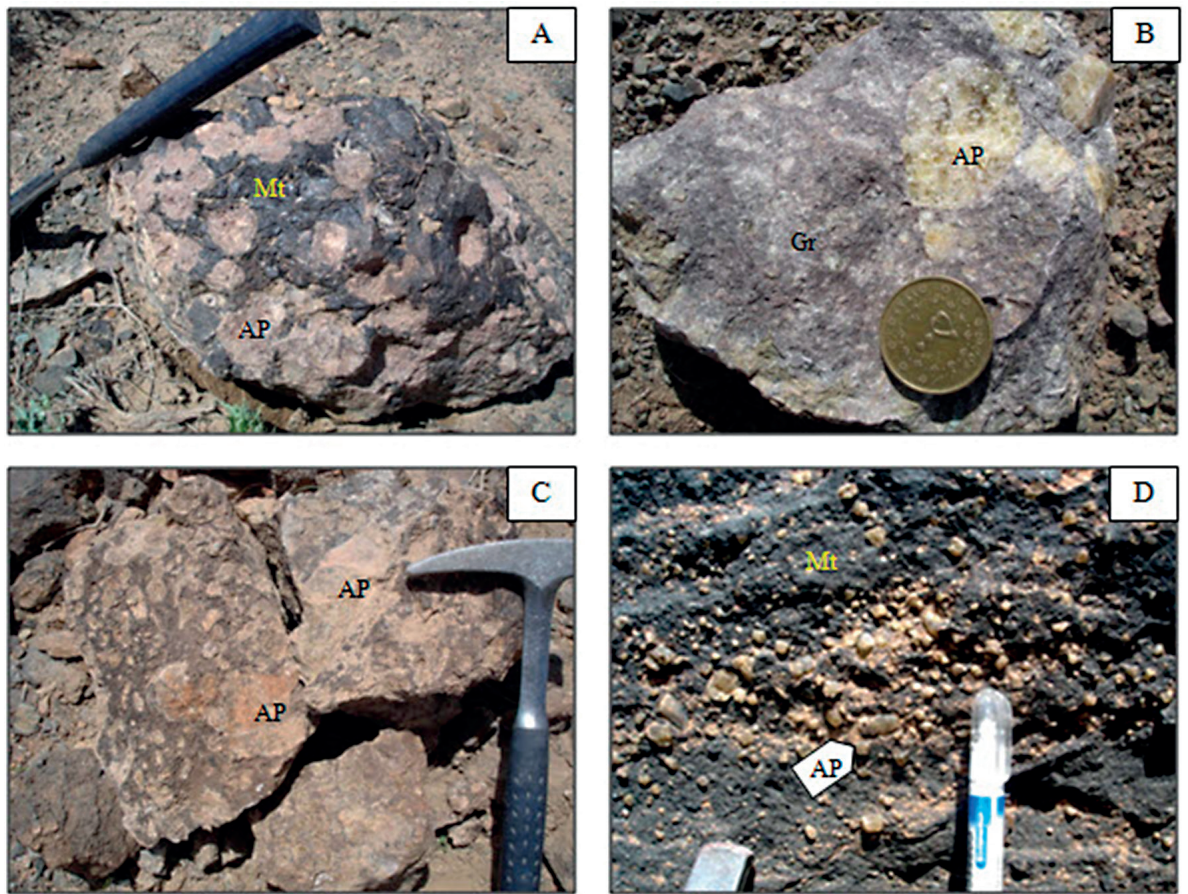

Fig. 3

Euhedral apatite crystals within the magnetite matrix (A: Esphordi deposit, D: Lak-e-Siah deposit) and within the green rocks (B: Esphordi deposit, C: Zarigan phosphate deposit). (Ap: apatite, Mt: magnetite, Gr: green rock) 
REE mineralization in the PBB is related to the IOA deposits (Abedian 1983; Darvish Zadeh 1983; Daliran 1990; Samani and Babakhani 1990; Samani 1998, 1999; Kryvdik and Mykhaylov 2001; Rahmani and Mokhtari 2002; Jami 2005; Mokhtari and Emami 2008; Torab and Lehman 2008; Torab 2010; Bumeri 2013; Mokhtari et al. 2013). In fact, enrichment in REEs is one of the specific characteristics of the IOA ores in this region. These elements are mainly concentrated in apatite crystals, but other minerals such as monazite, xenotime, bastnasite, urtite, alanite, thorite, parisite-synchysite and britholite, which are enriched in REEs, have been recognized (Kryvdik and Mykhaylov 2001; Jami 2005; Torab and Lehman 2008; Torab 2010; Bumeri 2013). These minerals are present as small inclusions within the apatite crystals, as well as in subsequently-emplaced carbonate, hematite-carbonate and quartz veins and veinlets (Kryvdik and Mykhaylov 2001; Jami 2005; Torab 2010; Bumeri 2013). Previous studies indicate that some of these inclusions were formed as primary deposits (Kryvdik and Mykhaylov 2001), but most of them were generated as secondary one as a result of later percolation of hydrothermal fluids (Jami 2005; Torab 2010; Bumeri 2013).

Geochemical investigations demonstrate that REE concentrations have a good positive correlation with $\mathrm{P}_{2} \mathrm{O}_{5}$ contents and negative correlation with Fe content (Mohamadi 2014). This is in turn indicative of REE concentrations within apatite and other phosphate minerals (e.g. monazite, xenotime and bastenasite).

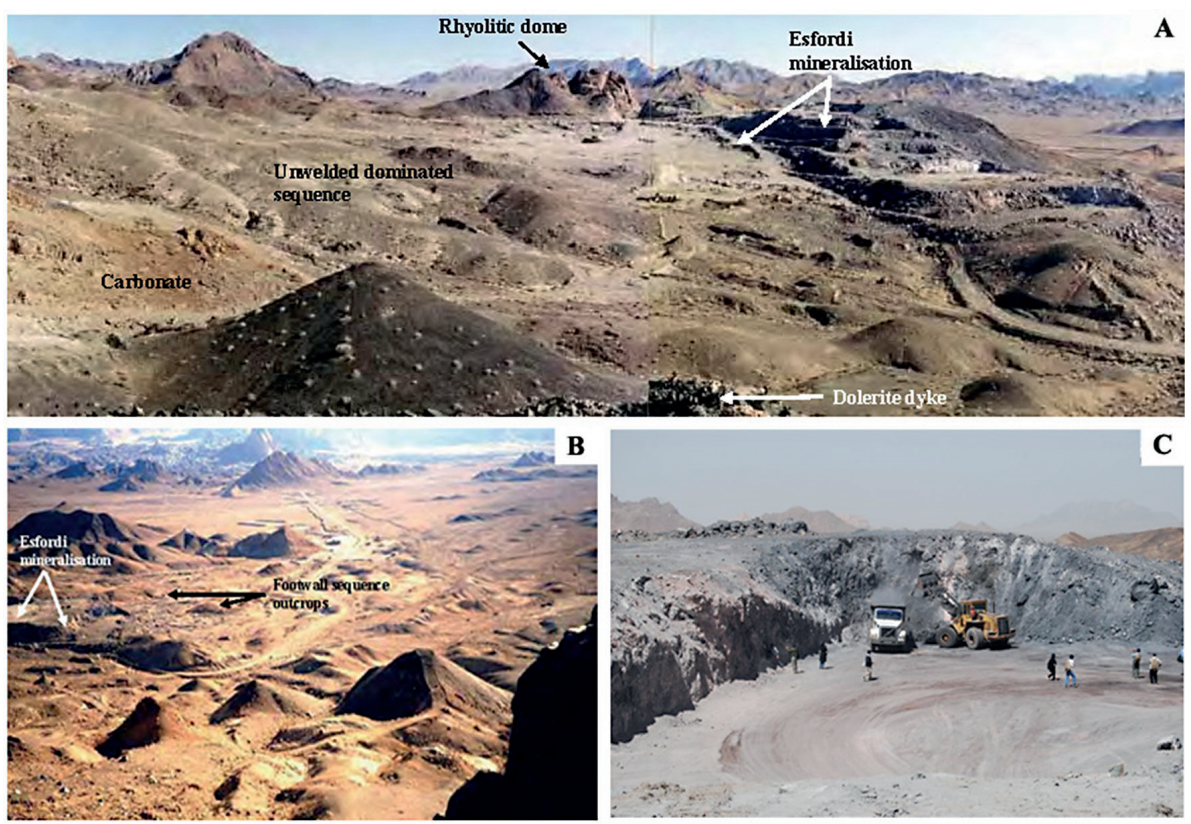

Fig. 4

Some views from the Esphordi P-Fe deposit. A: View to the SE, B: View to the S, C: Views from the exploitation site in the Esphordi P-Fe deposit (view to the SE). Figures A and B taken from Jami (2005) 


\section{Esphordi IOA deposit}

The Esphordi IOA deposit is hosted by a Cambrian-age sequence of volcano-sedimentary rocks (Jami 2005). This area is composed of rhyolite and rhyolitic tuff, dolomite, sandstone, altered volcano-sedimentary rocks, diabasic dykes and IOA ores (Jami 2005; Fig. 4). In this deposit, there is a main phosphatic zone which is mined for this purpose, and is called the Esphordi Phosphate deposit. Some previous investigations of the Esphordi deposit (Abedian 1983; Darvish Zadeh 1983; Samani and Babakhani 1990; Samani 1998, 1999; Daliran 1990; Kryvdik and Mykhaylov 2001; Jami 2005; Mokhtari and Emami 2008; Torab 2010) have demonstrated remarkable concentrations of REEs. There are inclusions of titanite, monazite, bastnasite, xenotime, britholite, parisite-synchysite, urtite and alanite within the apatite crystals, in which their concentration reach up to 2\% (Kryvdik and Mykhaylov 2001; Jami 2005;

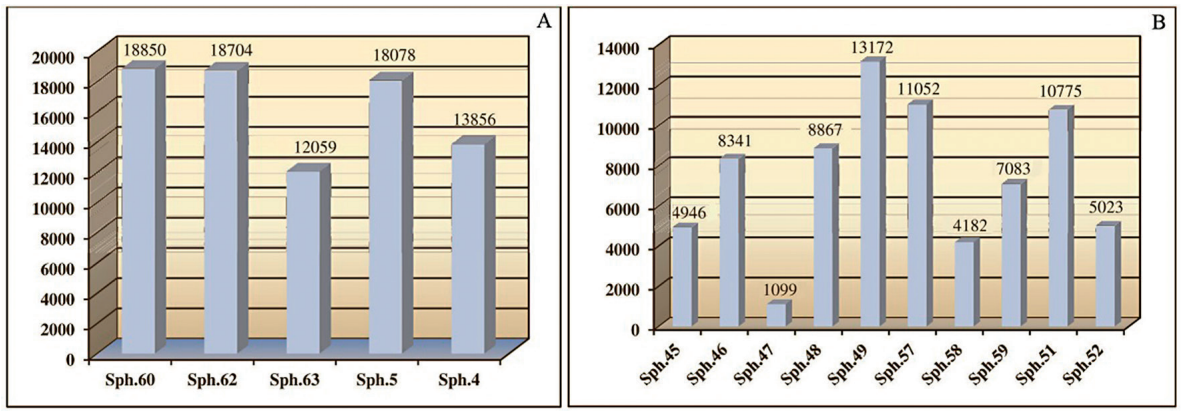

Fig. 5

A: REE concentrations in the samples from the Esphordi P-Fe deposit. B: REE concentrations in the samples from the IOA ores in the west of the Esphordi deposit (grades in ppm)
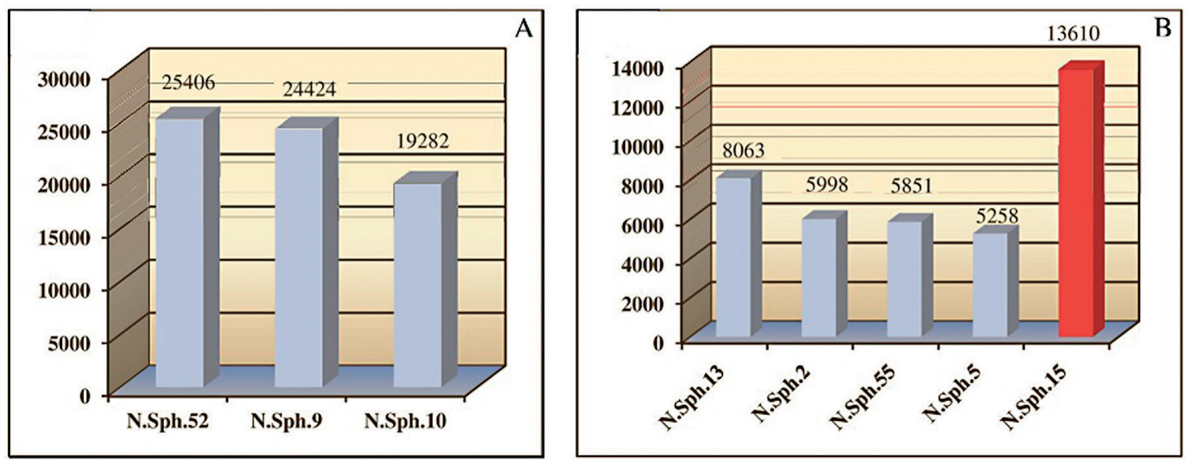

Fig. 6

A: REE concentrations in the samples from the apatite crystals from the IOA ores in the north of the Esphordi deposit. B: REE concentrations in the samples from the apatite-bearing magnetite ores and pyrite and hematite-bearing silica vein from the north of the Esphordi deposit (grades in ppm) 
Torab 2010, Bumeri 2013). REE content is directly related to the concentration of these inclusions (Kryvdik and Mykhaylov 2001; Jami 2005; Torab et al. 2008; Torab 2010).

Analysis of the samples from the Esphordi IOA deposit during this study indicates a higher grade of REEs, which varies between 1.2 and 1.9\% (Fig. 5). Furthermore, there are some small outcrops of IOA ores in the western part of the Esphordi deposit. REE content in these ores varies between 0.11 and $1.3 \%$ (Fig. 5). Lower grades belong to magnetite ores with negligible amounts of apatite. There are also some other small IOA ores that crops out to the north of the Esphordi deposit. The REE content in the apatite-bearing magnetite ores is between 0.5 and $0.8 \%$ (Fig. 8). Samples from the apatite crystals of these ores demonstrate higher grades of REEs between 1.9 and $2.5 \%$ (Fig. 6). One sample from the younger pyrite and hematite-bearing silica vein (N.Sph.15) indicates a high content of REEs (1.36\%), which is enriched in HREEs (Fig. 6).

\section{Gazestan IOA deposit}

This deposit is composed of Upper Proterozoic to Cambrian green rocks that are surrounded by dolomite, shale and sandstone, along with intercalations of acidic lavas and tuffs and cherty layers of the same age (Fig. 7). Phosphate mineralization in this

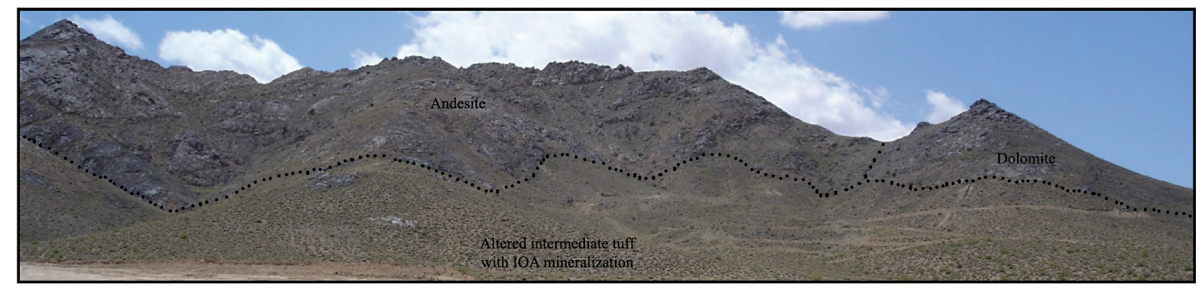

Fig. 7

A view from the Gazestan IOA deposit (view to the SW)
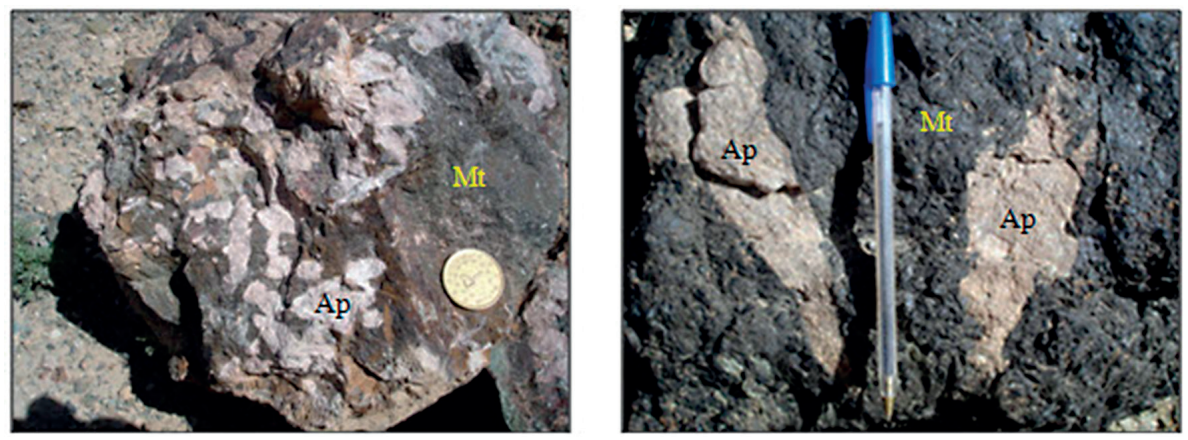

Fig. 8

Coarse-grained euhedral apatite crystals in the magnetite matrix at the Gazestan IOA deposit (Ap: apatite, Mt: magnetite) 
area is present as coarse-grained apatite crystals in the magnetite matrix (Fig. 8), phosphatic veins with minor accompaniment of magnetite and veinlets of finegrained apatite crystals within the green rocks. IOA ores are present as small lenses and veins within the altered green rocks. Based on Kryvdik and Mykhaylov (2001), mineralization in the Gazestan IOA deposit is poly-stage, where the first stage was one of magnetite-apatite mineralization and the later stage led to the

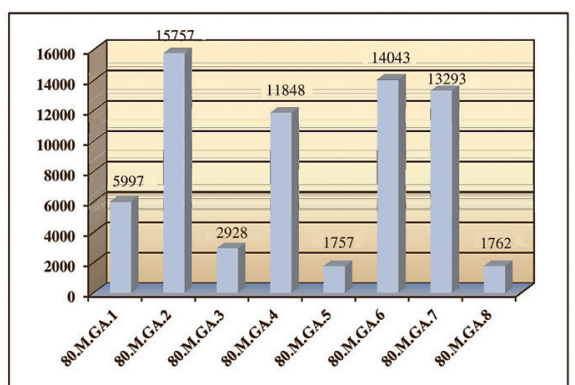

Fig. 9

REE concentrations in the samples from the Gazestan IOA deposit (grades in ppm) formation of the major phosphatic zone.

Kryvdik and Mykhaylov (2001) reported that the REE content in the Gazestan IOA deposit is about $1.5 \%$. The results of sample analysis in this study demonstrate that REE grades are between 0.17 and 1.57 percent (Fig. 9), being directly related to the $\mathrm{P}_{2} \mathrm{O}_{5}$ content.

\section{Zarigan phosphate deposit}

This area is made up of Upper Proterozoic-Cambrian rhyolite, syenite, granites and altered green rocks cut by diabasic dykes (Fig. 10). These altered rocks contain diopside, apatite, tremolite-actinolite and some calcite and quartz. Unlike the other IOA deposits of the PBB, this deposit includes only some phosphatic veins (up to $1 \mathrm{~m}$ in thickness) that are coarse-grained and of pegmatoidic texture (Fig. 11); iron oxide mineralization is absent in this deposit. The phosphatic veins show a NE-SW trend.

Previous studies (Abedian 1983; Kryvdik and Mykhaylov 2001) indicated high grades of some REEs (involved La, Ce, Pr and Nd) within the apatite crystals of this deposit (more than 1\% for these 4 mentioned elements). The results of our studies demonstrate that the REE content in the whole rock samples from this deposit varies between 0.5 and $1.2 \%$ (Fig. 12).

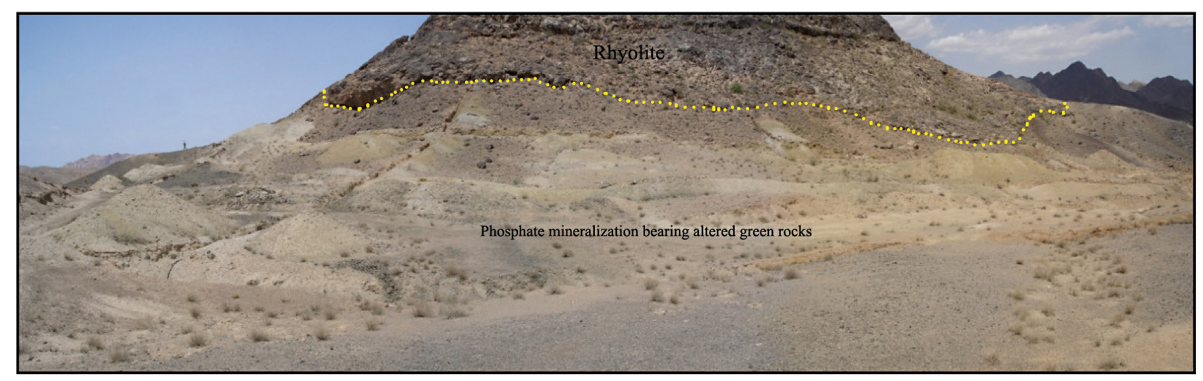

Fig. 10

A view from the Zarigan phosphate deposit in the hillside of rhyolite (view to the $\mathrm{N}$ ) 

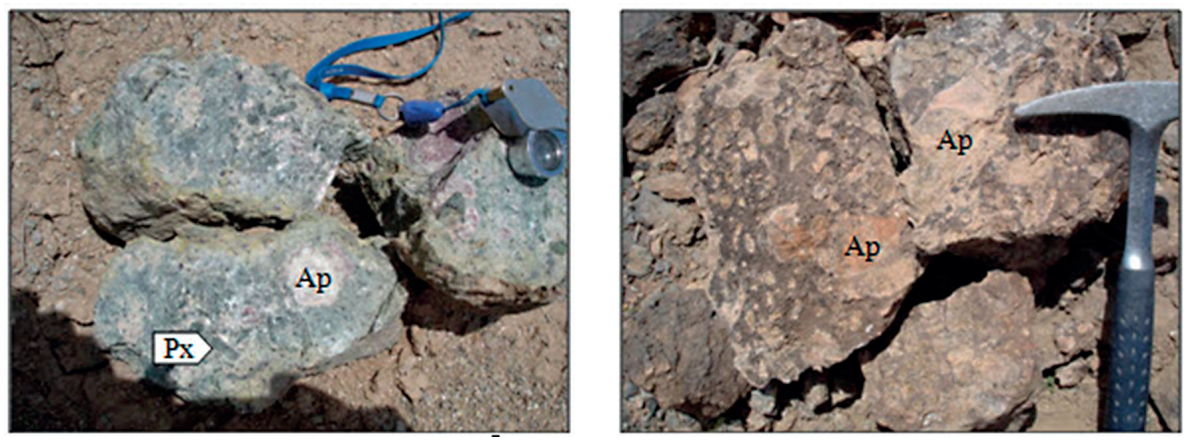

Fig. 11

Coarse-grained euhedral apatite within the green rocks at the Zarigan phosphate deposit (Ap: apatite, Px: pyroxene)

\section{Lak-e-Siah IOA deposit}

This area consists of rhyolite and rhyolitic tuffs, intermediate tuffs and some dolomite. Small outcrops of syenitic and gabbroic intrusion are also present (Fig. 13). There are some green rocks (tremolite-actinolite-apatite) in some places. IOA ores can be seen as lenses and veins in this area. Mineralogically, they are composed of magnetite that underwent martitization. Phosphate mineralization

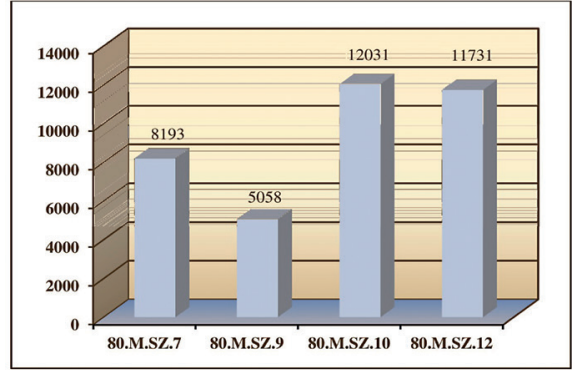

Fig. 12

REE concentrations in the samples from the Zarigan Phosphate deposit (grades in ppm)

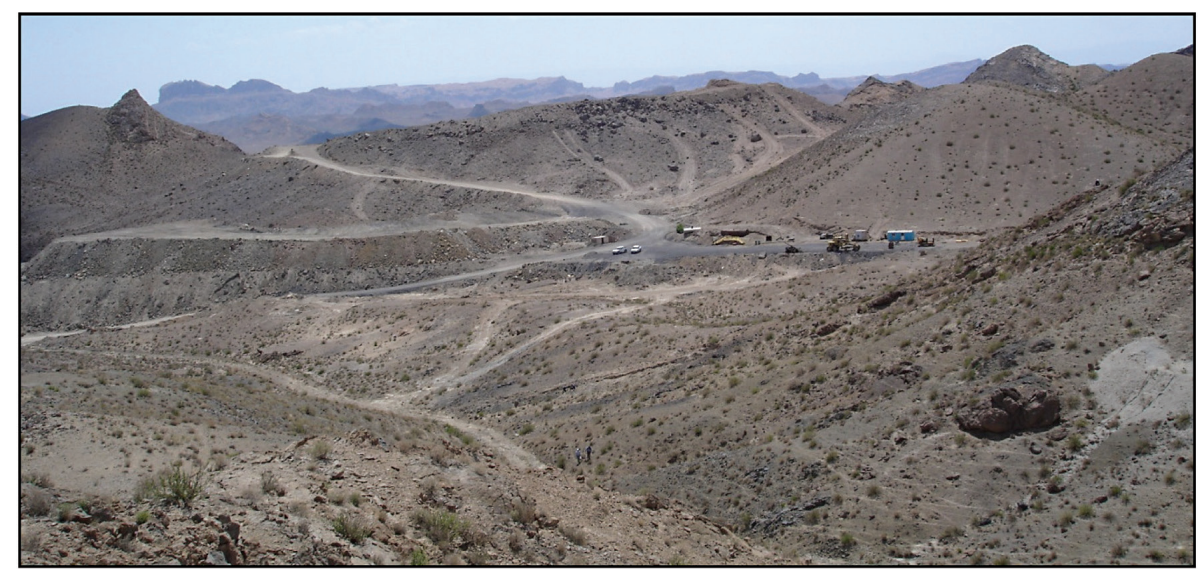

Fig. 13

View from the exploited Lak-e-Siah IOA apatite deposit (view to the SW) 

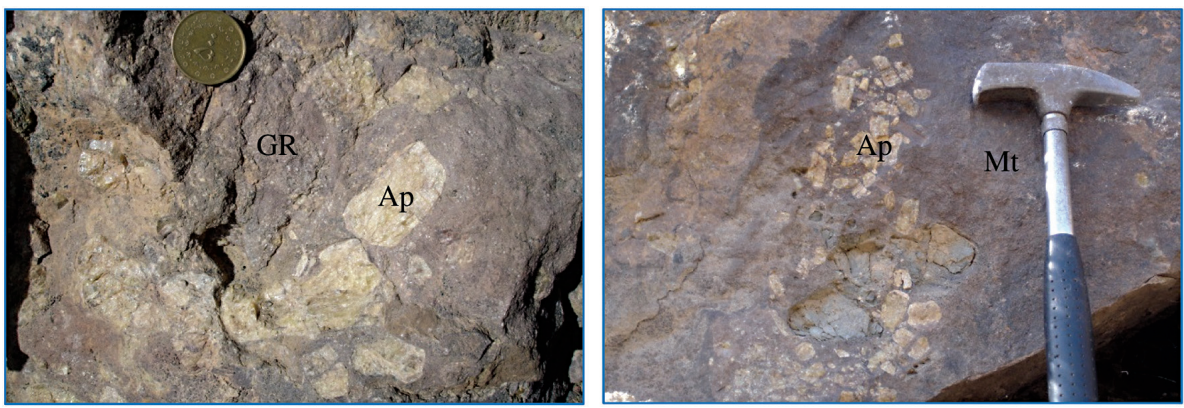

Fig. 14

Euhedral apatite crystals within the magnetite and green rocks at the Lak-e-Siah IOA deposit (Ap: apatite, Mt: magnetite, GR: green rock)
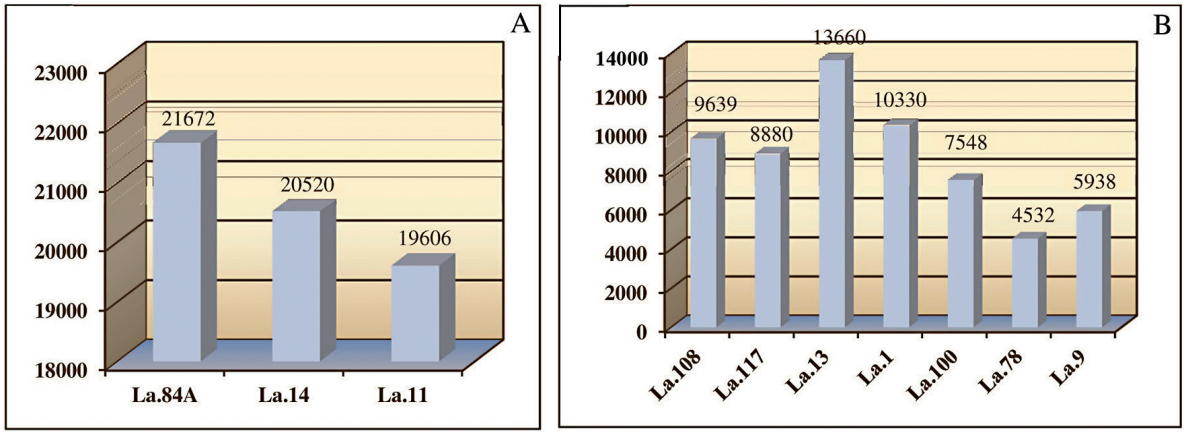

Fig. 15

A: REE concentrations in the apatite crystals within the IOA ores in the Lak-e-Siah deposit. B: REE concentrations in the samples from the apatite-bearing magnetite ores of Lak-e-Siah deposit (grades in ppm)

is present as veins and disseminated apatite crystals within the iron ores and green rocks (Fig. 14).

The analysis results of the samples from the apatite crystals demonstrate that the REE content varies between 1.96 and $2.16 \%$ (Fig. 15). In the samples from the apatite-bearing Fe ores, the REE content varies between 0.45 and $1.36 \%$ (Fig. 15).

\section{Other IOA deposits of the Posht-e-Badam Block}

The IOA deposits of Sechahoun, Mishdovan, Chahgaz, north of Chahgaz, Cheshmeh Firouzi, Shekarab and Homeijan also indicate high grades of REEs. Geologically and lithologically, these deposits are the same as the previously-mentioned IOA apatite deposits. Magnetite is the main form of mineralization in these deposits, which is martitized in some places. Phosphate mineralization is present as veins, veinlets and disseminated euhedral apatite crystals within or around the Fe ores. 

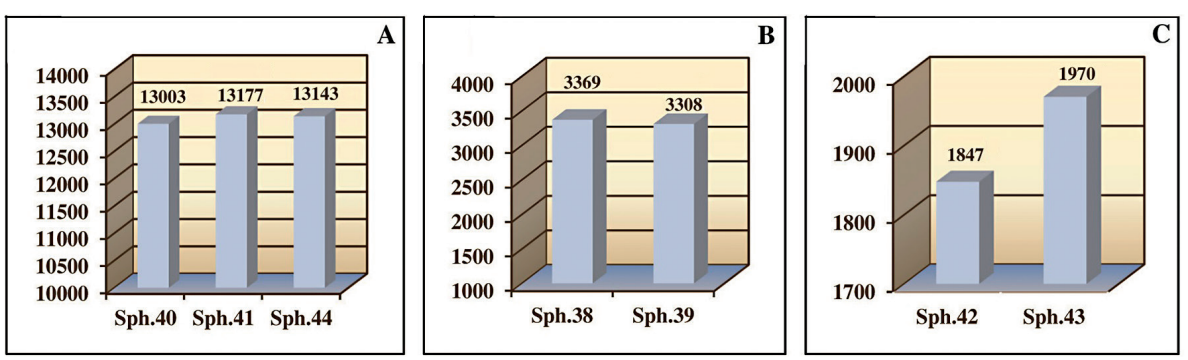

Fig. 16

REE concentrations in the phosphate concentrate (A), waste (B) and Fe concentrate in the Esphordi mine (grades in ppm)

Sample analyses from these deposits demonstrate somewhat high concentrations of REEs. Their REE contents are as follow: $0.24 \%$ in Sechahoun, $0.11 \%$ in Mishdovan, $0.09-0.15 \%$ in Chahgaz, $0.08-0.14 \%$ in NE Chahgaz, $0.13-0.28 \%$ in Cheshmeh Firouzi, $0.13 \%$ in Shekarab and $0.13-1 \%$ in the Homeijan deposit. Apatite crystals from the Homeijan IOA deposit indicate a $2.55 \%$ REE content.

\section{Esphordi mine products}

As mentioned in the previous sections, phosphatic and IOA ores from the Esphordi deposit have high contents of REEs. Thus it was decided to evaluate the REE concentration in the phosphate concentrate, Fe concentrate and waste of the Esphordi mine. These studies led to a remarkable result. Analyses of the samples from the phosphate concentration demonstrate that the REE content is about $1.3 \%$, samples from the Fe concentrate indicate 0.18 to $0.19 \%$ REE content and samples from the waste have $0.33 \%$ REE concentrations (Fig. 16).

\section{Conclusions}

The IOA deposits of the PBB are enriched in REEs. Among these deposits, the Esphordi, Zarigan, Gazestan and Lak-e-Siah deposits are the most important ones for REE mineralization and recommended for future exploration programs.

Given the high content of REEs in the phosphate concentrate in the Esphordi mine, in view of the higher economic value (price) of these elements, the processing of REEs in this mine and other IOA deposits of the PBB must be taken into consideration.

Finally, it must be remembered that the Posht-e-Badam Metallogenic Block is a valuable zone for REE mineralization, and must therefore be considered as a mining asset. These elements are of considerable economic and technical value; ignoring the concentration of REEs in these deposits would be wasting a national treasure. 


\section{Acknowledgements}

This research is mainly the result of a rare element exploration project by the Geological Survey of Iran. Therefore, I would like to thank Eng. Korehi, the Head of the Geological Survey of Iran, Dr. Mehrpartou, the Exploration Assistant, and Eng. Abedian, the Manager of the Exploration Branch of Geological Survey of Iran, for their help in analyzing samples in the ALS-Chemex Laboratory.

\section{References}

Abedian, N. 1983: Detailed exploration on Esphordi phosphate deposit. - Geological Survey of Iran, Tehran, 68 p. (in Persian)

Alavi, M. 1991: Tectonic map of the Middle East. - Geological Survey of Iran, Tehran.

Berberian, M., G.C.P. King 1981: Towards a paleogeography and tectonic evolution of Iran. - Canadian Journal of Earth Science, 18, pp. 210-265.

Bumeri, M. 2013: Rare earth minerals in Esphordi magnetite-apatite ore deposit, Bafq district. Scientific Quarterly Journal, Geosciences, 22/85, pp. 71-82. (in Persian)

Daliran, F. 1990: The magnetite-apatite deposit of Mishdovan, east central Iran. An alkali rhyolite hosted Kiruna-type occurrence in the infra Cambrian Bafq metallotect. - PhD thesis, Univ. of Heidelberg, Geowiss. Abhandl., 37, 248 p.

Daliran, F. 1999: REE geochemistry of Bafq apatites: Implication for the genesis of Kiruna-type iron ores. - In: Stanley, C.J. et al. (Eds): Mineral Deposits: Processes to Processing. Balkema, Rotterdam, pp. 631-634.

Daliran, F. 2002: Kiruna-type iron oxide-apatite ores and apatitites of Bafq district, Iran, with an emphasis on the REE geochemistry of their apatites. - In: Porter, T.M. (Ed): Hydrothermal Iron Oxide Copper-Gold and Related Deposits. PGC Publishing, Linden Park, pp. 303-320.

Daliran, F., H.G. Stosch, P. Williams 2009: A review of the Early Cambrian Magmatic and Metasomatic events and their bearing on the genesis of the Fe oxide-REE-apatite deposits (IOA) of the Bafq District, Iran. - In: William, P.J. et al. (Eds): Smart Science for Exploration and Mining: Proceedings of the 10th Biennial SGA Meeting, Townsville, pp. 623-625.

Daliran, F., H.G. Stosch, P. Williams, H. Jamali, M.B. Dorri 2010: Early Cambrian Iron Oxide-ApatiteREE (U) Deposits of the Bafq District, East-Central Iran. - In: Corriveau, L., H. Mumin (Eds): Exploring for Iron Oxide Copper-Gold Deposits: Canada and Global Analogues. Geol. Assoc. Canada, Short Course Notes, 20, pp. 143-155.

Darvish Zadeh, A. 1983: Investigation of the phosphate in Bafq (Esphordi). - Journal of Science, University of Tehran, 28/1, pp. 2-24. (in Persian)

Forster, H.A., Jafar Zadeh 1994: The Bafq mining district in central Iran - a high mineralized infra Cambrian volcanic field. - Economic Geology, 89/8, pp. 1697-1721.

Frietsch, R., J.A. Perdahl 1995: Rare earth elements in apatite and magnetite in Kiruna-type iron ores and some other iron ore types. - Ore Geology, 9, pp. 489-510.

Haghipour, A. 1975: Etude geologique de la region de Biabanak-Bafq (Iran central): petrography et tectonique du scale Precambrian et de sa couverture. - PhD thesis, Grenoble University, $403 \mathrm{p}$.

Harlov, D.E., H.J. Forster, T.G. Nijland 2002: Fluid-induced nucleation of (Y+REE)-phosphate minerals within apatite: Nature and experiment. Part 1: Chlorapatite. - American Mineralogist, 87, pp. 245-261.

Jami, M. 2005: Geology, geochemistry and evolution of the Esphordi phosphate-iron deposit, Bafq area, Central Iran. - Unpublished PhD thesis, 403 p.

Kerr, I.D. 1998: Mineralogy, chemistry and hydrothermal evolution of the Pea Ridge Fe-oxide-REE deposit, Missouri, USA. - Unpublished MSc thesis, University Windsor, Ontario, 112 p. 
Kryvdik, S., V. Mykhaylov 2001: The potential of the rare earth mineralization of Islamic republic Iran. - National Academy of Science of Ukraine, Kiev, 48 p.

Long, K.R., B.S. Van Gosen, N.K. Foley, D. Cordier 2010: The Principal Rare Earth Elements Deposits of the United States; A Summary of Domestic Deposits and a Global Perspective: USGS. Scientific Investigations Report, 2010-5220. - http://pubs.usgs.gov/sir/2010/5220, 96 p.

Mohamadi, F. 2014: Geochemistry of Azim-Abad granitoid (SW of Bahabad) and its probable role in iron-apatite mineralization. - Unpublished MSc thesis, University of Zanjan. (in Persian).

Mokhtari, M.A.A., M.H. Emami, Sh. Rahmani 2003: REE mineralization in the Bafq-Posht-e-Badam region. - 22th Geoscience Symposium, Geological Survey of Iran. (in Persian)

Mokhtari, M.A.A., M.H. Emami 2008: REE pattern and REE mineralization in apatite-magnetite deposits of Bafq-Saghand district (Central Iran). - Geosciences, Scientific Quarterly Journal, Special Issue, 17/1, pp. 162-169.

Mokhtari, M.A.A., Gh. Hossein Zadeh, M.H. Emami 2013: Genesis of iron-apatite ores in Posht-eBadam Block (Central Iran) using REE geochemistry. - Journal of Earth System Sciences, 122/3, pp. 795-807.

NISCO 1980: Result of search and valuation works at magnetic anomalies of the Bafq iron ore region during 1976-1979. - Unpublished Report, National Iranian Steel Corporation, 260 p. (in Persian)

Parak, T. 1975: Kiruna iron ores are not intrusive magmatic ores of the Kiruna-type. - Economic Geology, 70, pp. 1242-1258.

Piccoli, P.M., P.A. Candela 2002: Apatite in igneous systems. - In: Kohn, M.J., J. Rakovan, J.M. Hughes (Eds): Phosphates (Reviews in Mineralogy and Geochemistry). Mineralogical Society of America and Geochemical Society, Washington, 48, pp. 255-292.

Rahmani, Sh., M.A.A. Mokhtari 2002: Exploration of metallic rare elements. - Geological Survey of Iran, Tehran, 365 p. (in Persian)

Ramazani, J., R.D. Tucker 2003: The Saghand region, Central Iran: U-Pb geochronology, petrogenesis and implications for Gondwana tectonics. - American Journal Science, 303, pp. 622-665.

Samani, B. 1993: Saghand formation, a riftogenic unit of upper Precambrian in central Iran. Geosciences, Geological Survey of Iran, 6, pp. 32-45. (in Persian)

Samani, B. 1998: Precambrian metallogeny in Central Iran. - Scientific Bulletin of the Atomic Energy Organization of Iran, 17, pp. 1-16. (in Persian)

Samani, B. 1999: Rare earth element mineralization in Precambrian of Central Iran. - Scientific Bulletin of the Atomic Energy Organization of Iran, 20, pp. 15-31. (in Persian)

Samani, B., A. Babakhani 1990: Geological evolution of the Bafq-Saghand region and metallogenic model for the iron-apatite and radioactive deposits. - 9th Symposium on Geosciences, pp. 24-25. (in Persian)

Stosch, H.G., R.L. Romer, F. Daliran, D. Rhede 2011: Uranium-lead ages apatite from iron oxide ores of the Bafq District, East-Central Iran. - Mineralium Deposita, 46, pp. 9-21.

Stöcklin, J. 1968: Structural history and tectonics of Iran: A review. - American Association of Petrology and Geology Bulletin, 52, pp. 1229-1258.

Taghizadeh, N. 1976: The iron ore deposits of Iran. - In: Zitzmann, A. (Ed): The Iron Ore Deposit of Europe and Adjacent Areas; Explanatory Notes to the International Map of the Ion Ore Deposits of Europe. Bundesanstalt fur Geowissenschaften und Rohstoffe, Hannover, pp. 199-202.

Torab, F.M. 2010: Geochemistry and radio-isotope studies on the iron-apatite ores in Bafq metallogenic zone for determination of apatite origin. - Iranian Journal of Crystallography and Mineralogy, 18/3, pp. 409-418. (in Persian)

Torab F.M., B. Lehmann 2008: Magnetite-apatite deposits of the Bafq district, Central Iran: apatite geochemistry and monazite geochronology. - Mineralogical Magazine, 71, pp. 347-363. 